\title{
Seminavis atlantica Garcia, a new psammic diatom (Bacillariophyceae) from southern Brazilian sandy beaches
}

\author{
Garcia, M.* \\ Departamento de Botânica, Universidade Federal de Pelotas, \\ CEP 96010-900 Pelotas, RS, Brazil \\ *e-mail: marines@ufpel.tche.br, marinesdiatoms@yahoo.com.br
}

Received March 13, 2006 - Accepted June 19, 2006 - Distributed November 30, 2007

(With 18 figures)

\begin{abstract}
The paper presents the description of Seminavis atlantica Garcia, a psammic marine diatom from dissipative sandy beaches from southern Brazil. It is characterized by its convex linear dorsal margin (37 to $50 \%$ of its length is in a straight line), linear ventral margin and raphe located very close to the ventral margin. Its morphology is compared to similar species such as Amphora clevei Grunow, Amphora angusta (Greg.) Cleve var. orientalis Allem, Amphora ventricosa Gregory and Amphora eulesteinii Grunow.
\end{abstract}

Keywords: benthic diatoms, Brazil, marine sandy beaches, new taxa, taxonomy.

\section{Seminavis atlantica Garcia, uma nova diatomácea psâmica (Bacillariophyceae) de praias arenosas do Sul do Brasil}

\begin{abstract}
Resumo
O trabalho apresenta a descrição de Seminavis atlantica Garcia, uma diatomácea psâmica marinha de praias arenosas dissipativas do Sul do Brasil. Esta é caracterizada por sua margem dorsal linear (37 a $50 \%$ do seu comprimento apresenta-se em linha reta), margem ventral linear, e rafe localizada muito próxima da margem ventral. Sua morfologia é comparada a espécies similares como Amphora clevei Grunow, Amphora angusta (Greg.) Cleve var. orientalis Allem, Amphora ventricosa Gregory, e Amphora eulesteinii Grunow.
\end{abstract}

Palavras-chave: diatomáceas bênticas, Brasil, praias arenosas marinhas, taxon novo, taxonomia.

\section{Introduction}

The genus Seminavis D.G. Mann was described in Round et al. (1990) and included in Naviculaceae because of the internal raphe fissure that opens laterally, its two plate-like plastids lying along each side of the girdle, and the presence of developed transapical ribs located internally on the valve face.

In LM microscopy, the features used to identify species of Seminavis are: the outline of the ventral margins, the shape of the apices, the length of striae on the dorsal valve face, the presence or absence of striation interruption on the ventral valve face, the shape and position of the raphe in relation to the ventral margin.

Seminavis has been revised and several new species have been described recently by Danielidis and Mann (2002 and 2003): S. basilica Danielidis, S. heidenii D.G. Mann, S. strigosa (Hustedt) Danielidis and EconomouAmilli, S.obtusiuscula (Grunow) Danielidis and D.G. Mann, S. latior (A. Schmidt) Danielidis and D.G. Mann,
S. cymbelloides (Grunow) D.G. Mann, S. ventricosa (Gregory) Garcia-Baptista, S. arranensis Danielidis and D.G. Mann, S. robusta Danielidis and D.G. Mann, S. macilenta (Gregory) Danielidis and D.G. Mann, and S. gracilenta (Grunow ex Schmidt) D.G. Mann. Two species, S. basilica and S. strigosa are commonly found on macroalgae and $S$. ventricosa, S. macilenta and, S. obtusiuscula were described for sublittoral sediments.

Garcia-Baptista (1993) studied sand samples from a dissipative marine sandy beach in southern Brazil and found a species that was identified following Hustedt (1955), and Foged (1975) Amphora ventricosa Gregory. After examining some specimens in SEM A. ventricosa was combined into Seminavis and named Seminavis ventricosa (Gregory) Garcia-Baptista mainly because of the presence of internal prominent transapical ribs between the striae and the internally twisted raphe system. Danielidis and Mann (2002) have redefined and 
emended the description of S. ventricosa (Gregory) Garcia-Baptista. Studying the type material, they proved Amphora ventricosa belongs to Seminavis but the type of Amphora ventricosa has a morphology distinct from the Brazilian specimens. In conclusion, the Brazilian species studied by Garcia-Baptista (1993) was not correctly identified. Therefore, the description of a new species is proposed.

\section{Materials and Methods}

Praia Azul (municipality of Arroio do Sal) is located on the coast in the northern part of Rio Grande do Sul State $\left(29^{\circ} 29^{\prime} \mathrm{S}\right.$ and $\left.49^{\circ} 49^{\prime} \mathrm{W}\right)$. The sediment is very well sorted, sub-round to round, very fine quartz (2.52 to $2.62 \phi)$. The shore is subject to microtides which have an amplitude of up to $2 \mathrm{~m}$. Samples were collected monthly from April 1990 to April 1991. Sand from the first centimetre was collected with a $3.7 \mathrm{~cm}$ diameter PVC tube and fixed with a $0.3 \%$ Lugol solution. Fixed material was stored in the Herbarium (ICN) of the Department of Botany, Universidade Federal do Rio Grande do Sul, Porto Alegre, Brazil, under the numbers 91001 to 91189 . Sand samples were cleaned following the Simonsen (1974) technique. Aliquots were dried on cover slips and mounted in Hyrax for permanent slides. Slides were examined with a Zeiss Axioplan light microscope with phase contrast and the specimens were photographed on Ilford Pan F 50. The diatoms drawings were made with the aid of a camera lucida attached to a Zeiss Standard $044 \mathrm{Br}$ microscope. For scanning electron microscopy (SEM), cleaned frustules were dried on a stub coated with gold at $1 \mathrm{kV}$ for 4 minutes, and examined with Jeol JSM6060 at an accelerating voltage of $20 \mathrm{kV}$. Terminology follows Round et al. (1990) and Barber and Haworth (1981).

\section{Results}

3.1. Seminavis atlantica Garcia sp. nov. (Figures 1-18)

Holotypus: ICN 91079 Praia Azul, Rio Grande do Sul, Brazil Brazil

Isotypus: ICN 91014 Praia Azul, Rio Grande do Sul, Brazil

Locus typicus: Praia Azul, Rio Grande do Sul,

\subsection{Studied material}

BRAZIL, Rio Grande do Sul, Praia Azul: April 1990 (ICN 91013, 91014, 9106, 91019)

October 1990 (ICN 91079)

February 1991 (ICN 91144)

\subsection{Diagnosis}

Frustulum apicibus rotundatis. Valva margine dorsali lineari-convexa et margine ventrali recta, 64.5-100 $\mu \mathrm{m}$, 7-12 $\mu \mathrm{m}$ longa, 7-12 $\mu \mathrm{m}$ lata. Area axialis multo angusta in facie dorsali valvae. Raphe multo proxima marginis ventralis. Striae dorsales et ventrales parallelae, 11-14 per $10 \mu \mathrm{m}$. Striae centrales e facie dorsali valvae leviter reductae in longitudine. Taeniae apertae.

The frustule is linear with round apices (Figures 1-6). The valve is $64.5-100 \mu \mathrm{m}$ long and $7-12 \mu \mathrm{m}$ wide with a convex-linear dorsal margin (37 to $50 \%$ of its length is in straight line). The ventral margin is straight, and the apices are cuneate produced (Figures 1, 2, 4, and 5). The axial area is almost invisible at LM on the ventral side and is present on the dorsal side (Figures 1, 2, 4, and $5)$. The raphe is located very close to the ventral margin (Figures 7-11). Externally, the raphe is straight. The central endings are slightly expanded and deflected towards the ventral side (Figures 8, 9). The distal ends are hooked towards the dorsal side (Figures 12, 13). Internally, the
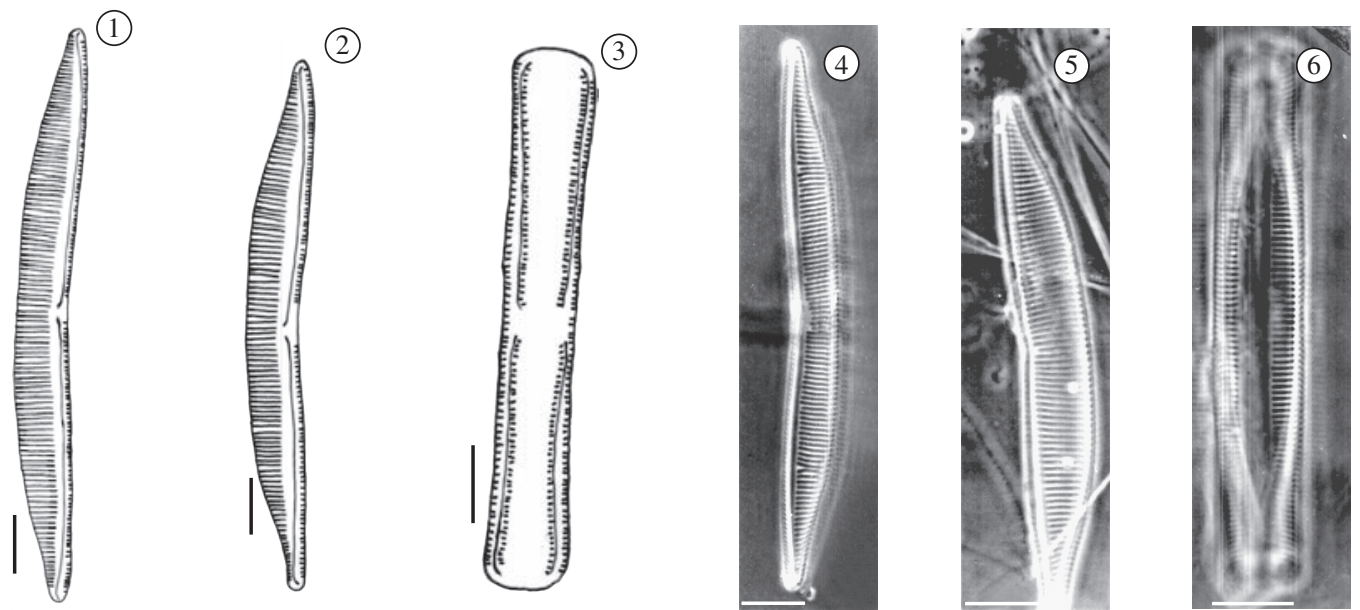

Figures 1-6. 1-2) General valve views; LM drawings; 3) Girdle view; LM drawings; 4-5) General valve views; phase contrast photographs; and 6) Girdle view; phase contrast photograph. Scale: $10 \mu \mathrm{m}$. 
raphe runs on a rib, which is turned over towards the dorsal side and twists into the vertical position at the center and poles (Figures 11, 14, 15). At the center, the proximal raphe endings are on a small nodule (Figures 16, 17) and the distal ones end in helictoglossa (Figures 14, 15). A single row of simple pores is present at both valve apices (Figures 14, 17). The dorsal and ventral striae are parallels $11-14$ in $10 \mu \mathrm{m}$. They are slightly reduced in length at the center on the dorsal side, and composed of elongated areolae (Figures 12, 18). At the central nodule on the ventral side the striae are absent (Figures 9, 10, 17). The ventral mantle is essentially absent; the dorsal mantle is deep and has no clear boundary with the valve face. The girdle is composed of plain open bands. The valvocopula is wider then other bands (Figures 8,13)

Seminavis atlantica occurs sporadically in the samples. It occurs in the middle of the beach more often than in the swash zone. The maximum number of frustules counted in October 1990 was of 1.400 frustules $/ \mathrm{cm}^{3}$ in a sample collected $30 \mathrm{~m}$ from the dune line and $30 \mathrm{~m}$ from the swash zone. In this sample the environmental parameters were: $\mathrm{pH}$ : 6.5 ; electric conductivity: 878 ; Na: $617 \mathrm{ppm}$; $\mathrm{NH}_{4}^{+}: 2 \mathrm{ppm}$, and P: $5 \mathrm{ppm}$. The range in environmental parameters of 6 samples where $S$. atlantica was present were: $\mathrm{pH}$ : 6.5-7.0; electric conductivity: 27.1-2660; Na: 20-672 ppm; $\mathrm{NH}_{4}^{+}:<1-30$ ppm, and P: 3-8 ppm.

\section{Discussion}

Remarks on similar species to Seminavis atlantica (A. clevei, A. eulensteinii, A. angusta var. orientalis and $S$. ventricosa) are as follows.

4.1. Amphora clevei Grunow in A. Schmidt Atlas, pl. 25, Figures 46-48, 1885.

A detailed examination of Schmidt's (1885) drawings of Amphora clevei reveals some similarities with $S$. atlantica as the somewhat linear in outline frustule, the semi-lanceolate hyaline area, and the shorter striae at the centre on the dorsal valve face. However, they differ by the slightly biarcuated ventral margin and the capitate apices, characteristics which are totally absent in $S$. atlantica. Foged (1984) published a micrograph of A. clevei measuring $87 \mu \mathrm{m}$ in length, $12 \mu \mathrm{m}$ in width, and with 11 striae in $10 \mu \mathrm{m}$ that differs from the drawings of Schmidt (1885) with regard to the central striae interruption on the ventral side, the dorsal striae of equal length on the valve face and the presence of rostrated apices.

\subsection{Amphora angusta (Greg.) Cleve var. orientalis Allem, Meddelanden från Göteborgs Botaniska Trädgård, 18: 322, Figure 2E, 1950.}

The main distinguishing features between this species and $S$. atlantica are the more centrally located raphe on the valve face, the continuity of the ventral striae at the centre, and the slightly curved dorsal striae. The dimensions are 35 to $65 \mu \mathrm{m}$ long, 2 to $9 \mu \mathrm{m}$ wide, and 22 striae in $10 \mu \mathrm{m}$ in both valve faces. These features are very distinct from $S$. atlantica. Amphora angusta var. orientalis is an epiphytic species on macroalgae according to Allem (1950).

\subsection{Amphora ventricosa Gregory, Trans R. Soc. Edinb.,} 21. 1857.

The most similar figures illustrated in the literature with our specimens are the ones presented by Foged (1975) from Tanzania. Especially Figures 7, 8, and 9 in the Plate 26 resemble $S$. atlantica. They differ in the wider axial dorsal area and the rhombic dorsal margin (Figures 8 and 9). Special reference must be made regarding Figure 7 where a somewhat linear convex dorsal margin is present. Foged (1975) found A. ventricosa in scrapings from an old trunk.

Hustedt (1955) also recorded this taxon as Amphora angusta var. ventricosa (Greg.) Cleve in mud samples from North Carolina.

4.4. Amphora eulensteinii Grunow in A. Schmidt Atlas, pl. 25, Figures 1-3 and pl. 40 Figures 35-37, 1885.

Sinonym: Amphora angusta (Gregory) Cleve var. eulensteinii (Grunow) Cleve.

Mann (1925) referred to this taxon as Amphora eulensteinii and commented on its unsatisfactory inclusion as a variety of Amphora angusta by Cleve (1895).

Amphora eulensteinii is illustrated in Schmidt (1885) with clearly punctated striae, a wide dorsal axial area, a slightly concave ventral margin and obtusely round apices, features which differ S. atlantica from A. eulensteinii. It was found by Giffen (1970, 1973, 1975, and 1976) and illustrated in Giffen (1973) presenting concave dorsal margin, raphe located more centrally on the valve face and ventral striae interrupted at the centre. Amphora eulensteinii was common on masses of several seaweeds and sand bottoms in South Africa.

\subsection{Seminavis basilica Danielidis, Diatom Research,} 18: 22, Figures 1-9. 2003.

Seminaivs basilica differs from $S$. atlantica in several aspects: the general valve outline which is rombic-lanceolate; the dimensions (valve size and number of striae) which are higher; the shape of extremities which are truncated; the absence of striae interruption on the ventral side; the deflection of the proximal raphe endings; the weight of the ventral side of the valve. The presence of a groove between the striae and axial area on the dorsal side in S. basilica is another important feature which differentiates one species from the other. Seminavis basilica is an epiphytic diatom on macroalgae.

In conclusion, $S$. atlantica is a free moving diatom among sand grains characterized by its linear ventral margin, raphe located very close to the ventral margin, and the unique feature of a rectilinear dorsal margin with 37 to $50 \%$ of its length in a straight line.

Acknowledgments - I am thankful to Dr. Jorge Fontonella Pereira (Herbarium Bradeanum, Rio de Janeiro) for the latin diagnoses and to Dr. Lezilda C. Torgan for the free access to her private library. This work has been partially supported by CNPq 301897/2003-4 


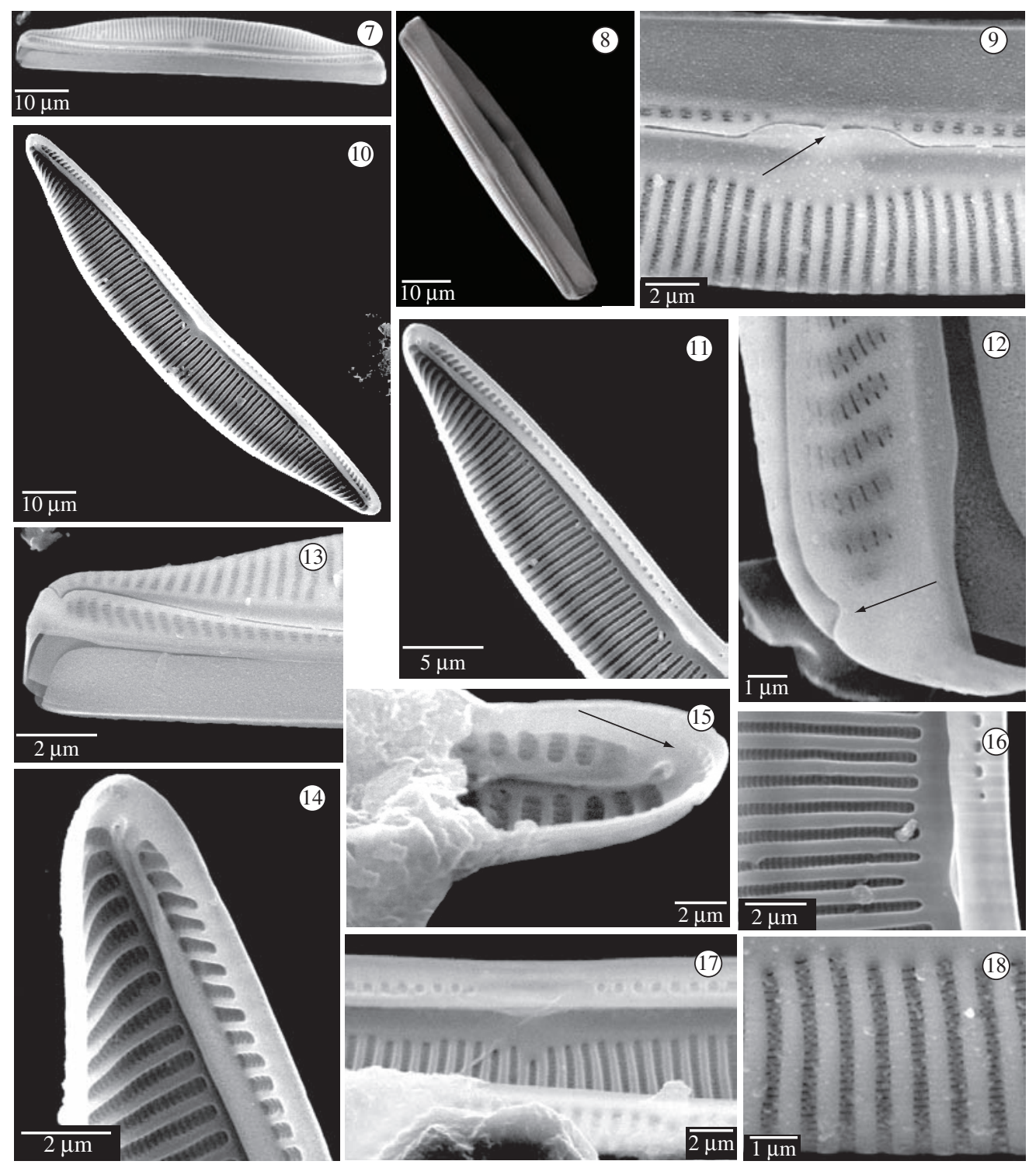

Figures 7-18. SEM. 7) External general view showing the valve face and valvocopula; 8) Another external view of a valve with valvocopula; 9) Detail of external central raphe end reflected towards the ventral side (arrowed); 10) Internal general view; 11) Detail of figure 10 showing the raphe running on a rib; 12) Detail of figure 7. showing a distal raphe end and showing in detail the elongated areolae. Note the raphe distal ends turned to dorsal side (arrowed); 13) Apex of a valve showing the external distal raphe end; 14) Another view of an apex, internally; 15) Detail of a distal raphe end and helcitoglossa. Note the presence of a row of simple pores at apex (arrowed); 16) Internal view of a valve centrally showing a small nodule where the proximal raphe terminates and the twisted raphe rib; 17) Internal valve view showing the raphe rib; and 18) Detail of areolae externally.

\section{References}

ALLEM, AA., 1950. Littoral diatoms from the eastern Mediterranean. Meddelanden från Göteborgs Botaniska Trädgård, vol. 18, p. 309-325.

BARBER, HG. and HAWORTH, E., 1981. A guide to the morphology of the diatom frustule. Crumbia: Freshwater Biological Association. (Scientific Publication, 44). Cumbria, 112 p.
CLEVE, PT., 1895. Synopsis of the naviculoid diatoms. $K$ Svenska Vetenskaps-Akad. Handl., vol. 26, no. 2, p. 1-194.

DANIELIDIS, DB. and MANN, DG., 2002. The systematics of Seminavis (Bacillariophyta): the lost identities of Amphora angusta, A.ventricosa and A. macilenta. Eur. J. Phycol., vol. 7, no. 3 , p. $429-448$.

-, 2003. New species and new combinations in the genus Seminavis (Bacillariophyta). Diatom Res., vol. 18, no. 1, p. 21-39. 
FOGED, N., 1975. Some littoral diatoms from the coast of Tanzania. Bibl. Phycologica, vol. 16, p. 1-127.

-, 1984. Freshwater and littoral diatoms from Cuba. Bibl. Diatomologica, vol. 10, p. 1-119.

GARCIA-BAPTISTA, M., 1993. Psammic algae from Praia Azul, Brazil. Bibl. Phycologica, vol. 94, p. 1-167.

GIFFEN, MH., 1970. New and interesting marine and littoral diatoms from Sea Point, near Cape Town, South Africa. Bot. Mar., vol. 13, no. 2, p. 87-99.

-, 1973. Diatoms of the marine littoral of Steenberg's Cove in St. Helen Bay, Cape Province, South Africa. Bot. Mar., vol. 16, no. 1, p. 32-48.

-, 1975. An account of the littoral diatoms from Langebaan, Saldanha Bay, Cape Province, South Africa. Bot. Mar., vol. 18, vol. 2, p. 71-95.

-, 1976. A further account of the marine littoral diatoms of the Saldanha Bay Lagoon, Cape Province, South Africa. Bot. Mar., vol. 19, no. 6, p. 379-394.
HUSTEDT, F., 1955. Marine littoral diatoms of Beaufort, North Carolina. Mar. Sta. Bull. Duke Univ., vol. 6, p. 1-67.

MANN, A., 1925. The diatoms of the Canadian Artic Expedition, 1913-18. Report of the Canadian Artic Expedition 1913-18, vol. 4, part f, p. 3-33. Ottawa, Editora F.A. Acland - Printer to the King's most excellent Majesty.

ROUND, FE., CRAWFORD, RM. and MANN, DG., 1990. The diatoms. Biology and morphology of the genera. Cambridge University Press, Cambridge. 747p.

SCHMIDT, A., 1874-1959. Atlas der Diatomaceen-kunde. O.R. REISLAND, Leipzig.

SIMONSEN, R., 1974. The diatom plankton of the Indian Ocean Expedition of R/V "Meteor" 1964-1965. "Meteor"Forsch.Ergebnisse, vol. 19, part d, p. 1-107. 